\title{
Creating a TRNSYS Model of Spiral Flow Flat Plate Solar Water Heater (SFSWH) and Comparing Unique Results with Parallel Flow Flat Plate Collector
}

\author{
Selvadhurai M, Vignesh ponmurugan S, Vijayakumar R, Dillibabu V
}

\begin{abstract}
A unique SFSWH system is proposed for domestic hot water in Kovilpatti, TamilNadu, $9^{\circ} 10 \mathrm{~N} 77^{\circ} 52 \mathrm{E}$. This SFSWH system is successfully simulated in TRNSYS Software and the results are clarified with the similarities of parallel flow solar water heater. Firstly, a complete model of spiral flow flat plate collector is formulated in TRNSYS software and taking into an account of heat transfer, outlet temperature and efficiency which are theoretically compared with parallel flow flat plate collector by means of TRNSYS simulation program. The SFSWH system performs a function with the assist of NASA surface Meteorology and solar energy year readings and with the assist of ISRO's solar calculator application relative to Kovilpatti, Tamilnadu, India. To prove the accuracy of TRNSYS model of the SFSWH, an experimental setup is done at kovilpatti and required results were obtained under kovilpatti weather conditions. The validation of this SFSWH TRNSYS model simulation program is completed by checking the similarities between the predicted results from software with original results. This SFSWH TRNSYS model result shows the SFSWH is functioned more effectively compared with conventional parallel flow water heater. Thus TRNSYS model is reliable and which alternates the experimentation.
\end{abstract}

Keywords-SFSWH - Spiral Flow Solar Water Heater, TRNSYS.

\section{INTRODUCTION}

The largest energy resource, which is available as renewable energy in the earth is nothing but a solar energy. Global warming makes the world to understand about the usage of renewable sources and gives the importance to reduce the hazardous environment created by the fossil fuels. The plenty of solar radiation available every day at kovilpatti as compared to other regions in Tamilnadu, India. The measurement of solar isolation on the flat surface of Kovilpatti is monthly average of $4.86 \mathrm{kWh} / \mathrm{m}^{2} /$ day. SFSWH has the main part of black paint coated flat copper plate collector which receives the direct solar rays. The another part of black paint coated tubes which is set as a spiral form and conveys water from cold sump to hot water storage tank. The natural heat absorption by tube water from

\footnotetext{
Revised Manuscript Received on 14 September, 2019.

Selvadhurai M, Assistant professor/Mechanical department, Easwari Engineering College, Ramapuram, Chennai, Tamilnadu, India. (Email: selvadhuraimariappan@gmail.com)

Vignesh ponmurugan S, Director, Ponmurugan \& co Constructions, Tuticorin, Tamilnadu, India. (Email: vigneshponmurugan.s@gmail.com)

Vijayakumar R, Assistant professor/Mechanical department, National Engineering College, Kovilpatti, Tuticorin, Tamilnadu, India. (Email: talk2vijayakumar89@gmail.com)

Dillibabu V, Assistant professor/Mechanical department, Easwari Engineering College, Ramapuram, Chennai, Tamilnadu, India. (Email:
} babudilli8@gmail.com) collector makes the high temperature water outlet. Transient simulation of systems is the simulation program, simply called as TRNSYS. This software gives the best simulation area for energy related systems. The complicated validation of new ideas in renewable energy systems (for example wind, solar, PV etc.) including their control areas can be done by TRNSYS. This software makes the easy way to extend the existing energy systems and makes the correct way of the user's optimized passive solar heating prototype. The TRNSYS model is validated with specific needs. We can make custom simulation for the user's requirement by creating the customized parts in TRNSYS software. S.Maheshwaran and K.Kalidasa Murugavel studied the behavior of spiral flow flat plate collector for kovilpatti (9o10’N, 77o52'E). Gurjot and Alan conducted an experiment as a hybrid model which is solar water heater with heat exchanger. Yanuar et al. did a work of heat exchanger with a spiral pipe using nano fluids. Mohammed et al. modeled and verified the project of $10 \mathrm{~m}^{2}$ horizontal plate collector with storage capacity of 600 liters to the usage need of 25 persons. Their system covers winter season's hot water requirement with an annual solar fraction of $69 \%$ in addition with auxiliary electric heater.

\section{METHODOLOGY}

SFSWH model is created in TRNSYS platform of simulation program and the required data is collected and the given methodology is followed to achieve the simulation. Initially the simulation is created in TRNSYS platform and also the unique results are obtained by experimentally. The entire setup is created and unique results are compared. 
Creating A Trnsys Model Of Spiral Flow Flat Plate Solar Water Heater (Sfswh) And Comparing Unique Results With Parallel Flow Flat Plate Collector

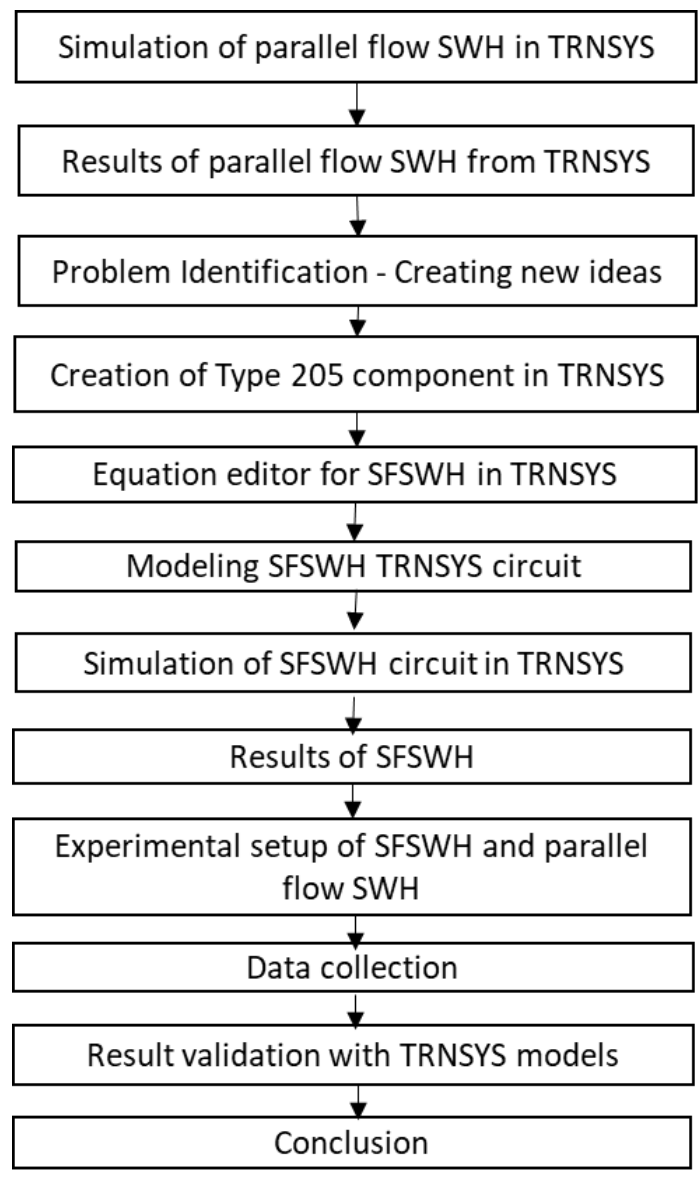

\section{SIMULATION OF PARALLEL FLOW SWH IN TRNSYS}

The parallel flow SWH system circuit is formulated in TRNSYS software with their all components. The output results of outlet water temperature for parallel flow $\mathrm{SWH}$ system is obtained from simulation.

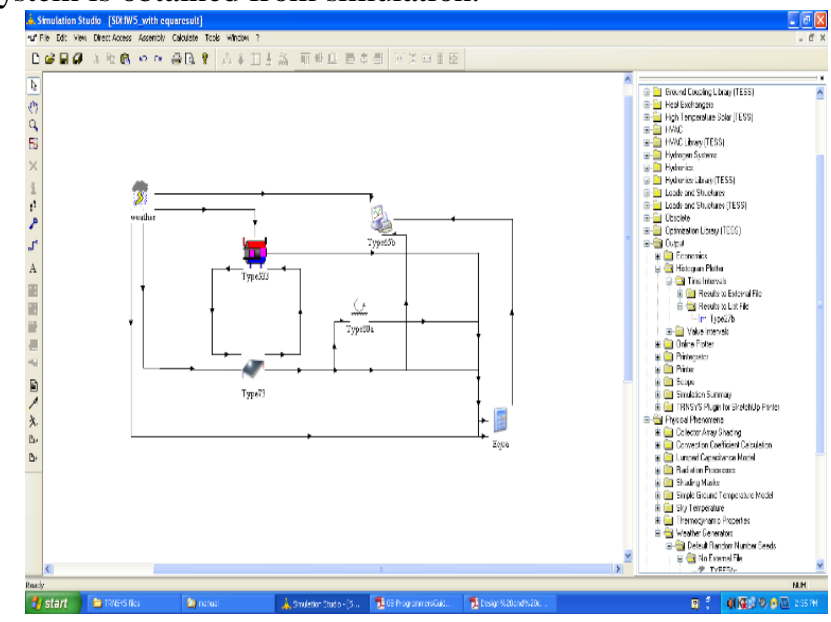

Fig. 1: Parallel flow SWH

\section{PROBLEM DEFINITION}

Solar thermal behavior with all parameters can be validated and verified by the simulation program called TRNSYS. But this software package has a limitation of mentioning the type of flow for simulation of annual performance for flat plate solar water heater in TRNSYS software. Usually, TRNSYS has the theoretical flat plate collector - Type 73 component commonly used in the simulation circuit system to mention the parallel flow SWH which does not give the actual output for spiral design.

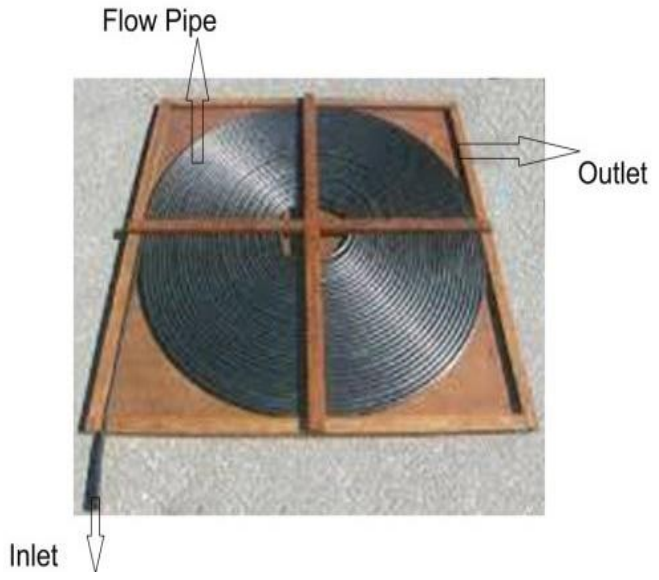

Fig. 2: Spiral Flow Design

The outlet temperature from spiral flow design in flat plate collector has the maximum value compared to parallel flow design. This is not achieved by Type 73 component in TRNSYS simulation program. So we need to create a new spiral flow model named as SFSWH TRNSYS model.

\section{CREATING NEW IDEAS}

\section{A. $\quad$ Creation of Type 205 component in TRNSYS}

The component Type 205 is created by assigning different variables related to SFSWH. The variable button of a proforma needs some of the weather data related to kovilpatti. The links between component Type 109 (weather data reading and processing) and Type $1 \mathrm{~b}$ and Type 205 are easily ensured by connecting one output with another input. Once, the component Type 205 is created we need to open it in TRNEdit. It reads the Type 205 component as TRNSED file. We can follow the default setup or we can modify the setup with programming language of FORTRAN.

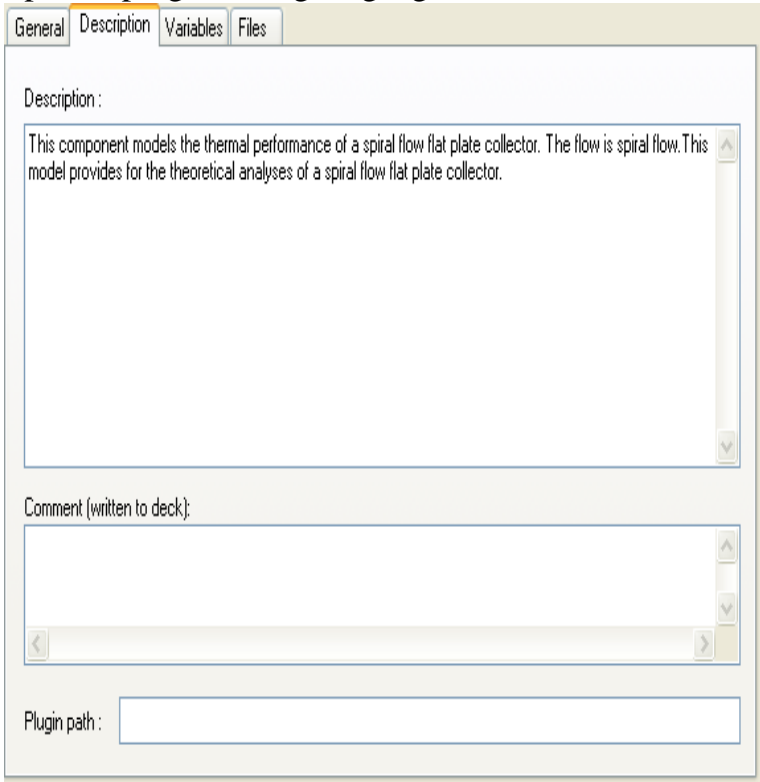

Fig. 3: Description of abstract 


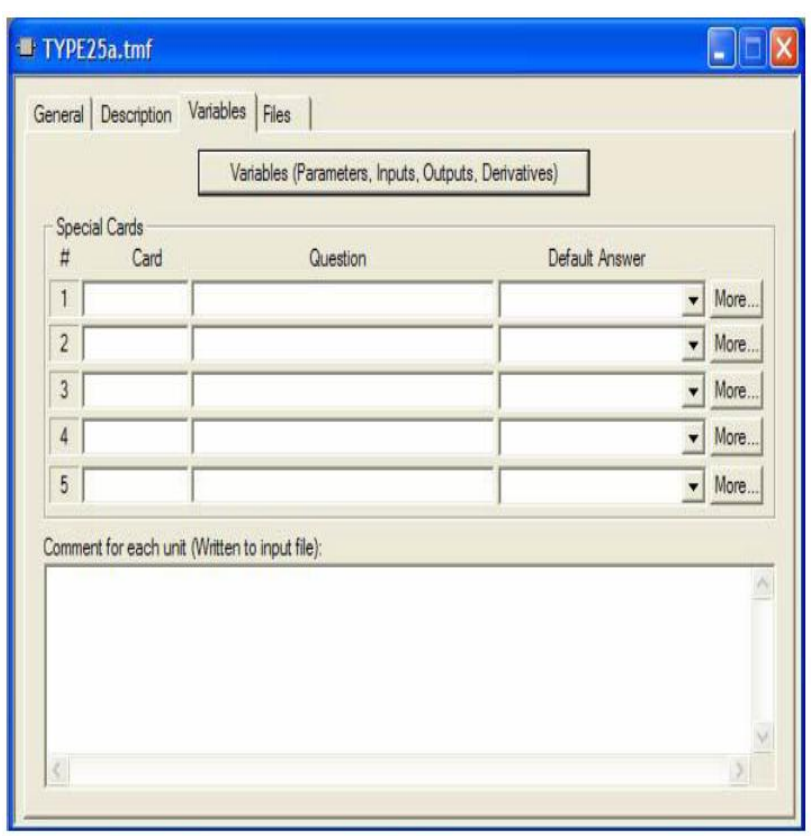

Fig. 4: Variables Tab

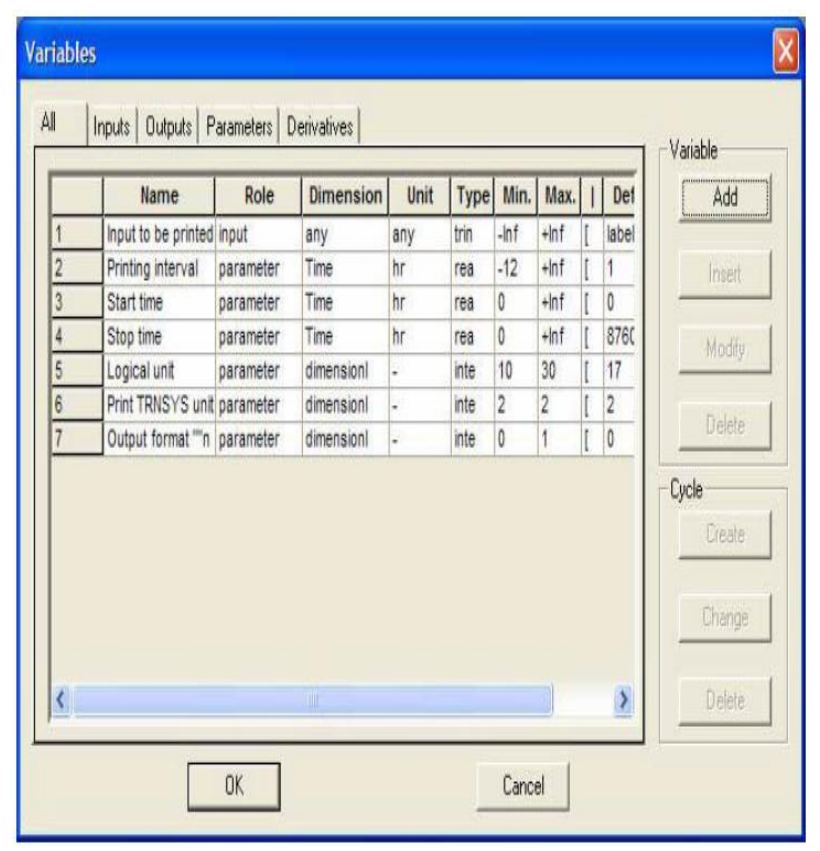

Fig. 5: Variables button

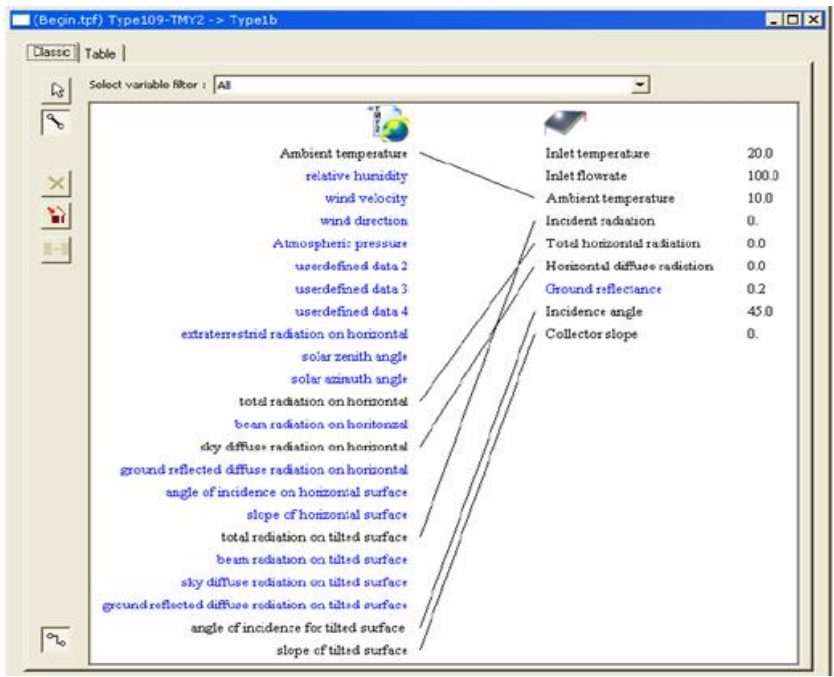

Fig. 6: Connections of components

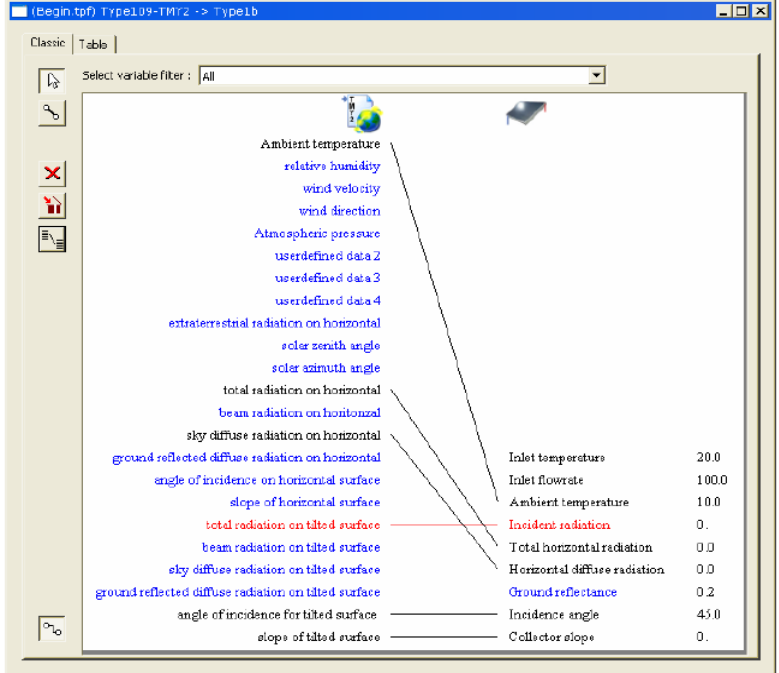

Fig. 7: Connections between weather and Type 205 component

\section{B. Equation editor for SFSWH in TRNSYS}

Even though the kovilpatti weather data gives the major role, the flow parameters are also considered in an account with the spiral flow equation. The equation editor setup is designed to predict the exact results based on the formulae.

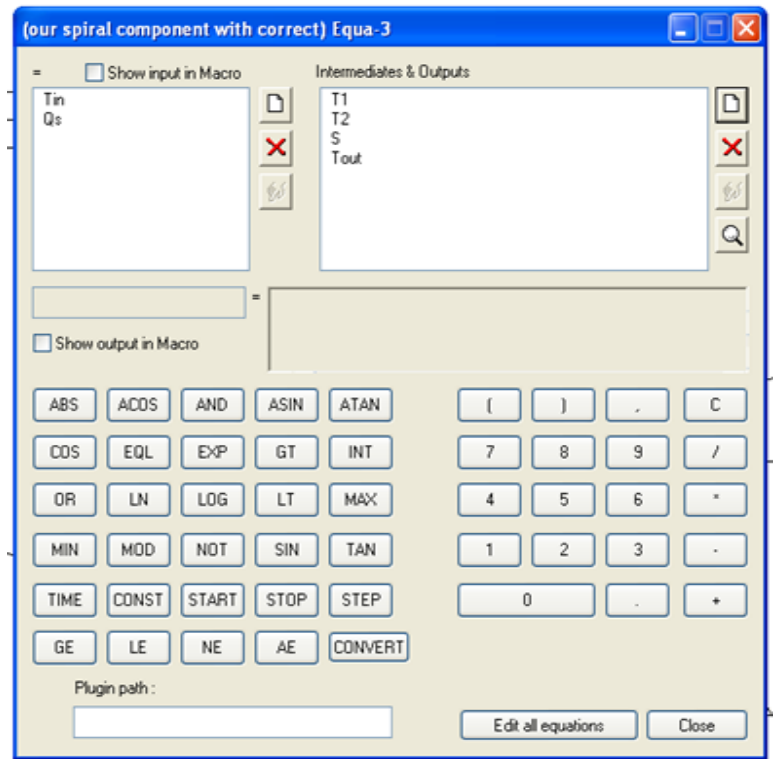

Fig 8: Equation Editor in TRNSYS Software

$\mathrm{D}=$ Diameter of inner pipe

$\Delta \mathrm{P}=$ Pressure drop

$\mathrm{L}=$ Pipe length (experimental portion)

$\mathrm{k}=$ Consistency of fluid

$\mathrm{n}=$ power law index

$\mathrm{u}=$ average velocity

$\Delta \mathrm{h}=$ head gradient

$\mathrm{H}\{\mathrm{x}\}=$ heat transfer co efficient at any point $\mathrm{x}$ in inlet $\mathrm{T}\{\mathrm{x}\}=$ Temperature of water at any point $\mathrm{x}$ $\mathrm{Qs}=$ heat flux

$\{(\mathrm{D}) *(\Delta \mathrm{P})\} /\{4 *(\mathrm{~L})\}=(\mathrm{K}) *\left\{\left[\left(8^{*} \mathrm{u}\right) / \mathrm{D}\right] \mathrm{n}\right\}$

$\mathrm{n}=\{(\mathrm{d} \ln (\mathrm{D} \Delta \mathrm{P} / 4 \mathrm{~L}))\} /\left\{\left(\mathrm{d} \ln \left(8^{*} \mathrm{u} / \mathrm{D}\right)\right)\right\}$

Darcy Equation gives coefficient of friction.

$\{f\}=$

Published By:

Blue Eyes Intelligence Engineering

\& Sciences Publication

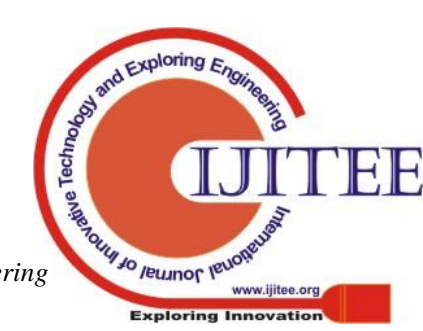


$\{(\mathrm{D} / \mathrm{L})\} *\{(2 \mathrm{~g} / \mathrm{u} 2) * \Delta \mathrm{h}\}$

$\{\mathrm{h}(\mathrm{x})\}=(\mathrm{Qs}) /\{(\mathrm{T} \neg \mathrm{s}(\mathrm{x})-\mathrm{Tb}(\mathrm{x}))\}$

$\{\mathrm{T}(\mathrm{x})\}=(\mathrm{Tb}, \mathrm{i})+\{(\mathrm{Q} s . \mathrm{P} / \mathrm{m} * \mathrm{Cp})\}$

$\mathrm{Qs}=\left\{\left((\mathrm{m}) *(\mathrm{Cp})^{*}(\mathrm{~Tb}, \mathrm{o}-\mathrm{Tb}, \mathrm{i})\right) / \mathrm{A}\right\}$

\section{SIMULATION OF SFSWH CIRCUIT IN TRNSYS}

The entire SFSWH circuit is drawn in the TRNSYS platform. The required data is feed to the individual components which are key role to the simulation. The weather data, supporting equations, links between the weather data with components like that all essential steps are taken to fit the SFSWH model in the TRNSYS simulation program. The arrow mark shows the direction of data transfer from one component to another component. For example, Type 109 component (weather data) is directly connected with Type 205 component. The actual weather data is directly feed into the component like if the level of radiation is high and then outlet temperature also increases with respect to the connection of links in variables proforma. This simulates the actual working condition in the software. After the simulation, the SFSWH results such as outlet temperature is very high compared to parallel flow SWH.

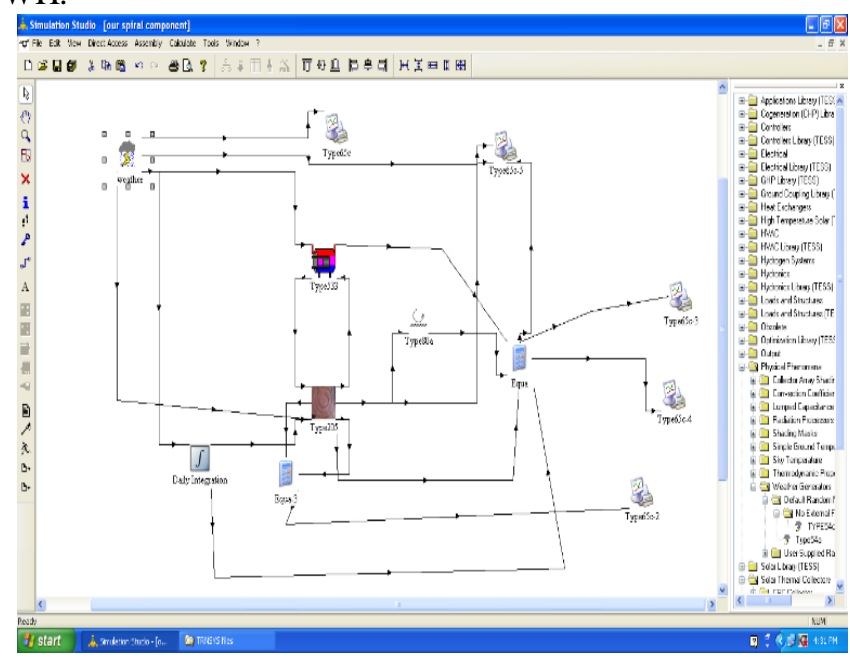

Fig. 9: SFSWH TRNSYS model

\section{EXPERIMENTAL ANALYSIS WITH DATA COLLECTION}

The SFSWH and parallel flow SWH models are lively created and continuous monitoring is done to compare the unique results with the simulation software. The setup specification is as mentioned in Table.

Table.1: Component specifications

\begin{tabular}{|l|l|}
\hline Tank capacity & 53 litre \\
\hline Spiral flow pipe & Copper (length=9m) \\
\hline Outer radius & $16 \mathrm{~mm}$ \\
\hline Inner radius & $14 \mathrm{~mm}$ \\
\hline Absorber plate & Aluminium sheet \\
\hline Glass cover & $5 \mathrm{~mm}$ thickness $\left(100 \mathrm{~cm}^{*} 100 \mathrm{~cm}\right)$ \\
\hline Insulation & Thermocol, Coconut Fiber \\
\hline
\end{tabular}

The readings are obtained half an hour base while the experimentation is going on.

1. Inlet temperature.

2. Outlet temperature.

3. Ambient temperature.

4. Glass temperature.

5. Solar intensity.

There are two measurements were taken for the different flows. Reading of the experimentation is taken by author. The parallel flow SWH and SFSWH readings are taken at the location of kovilpatti, Tamilnadu. The figure shows the complete setup of parallel flow SWH. The outlet temperature of parallel flow SWH is in Table.

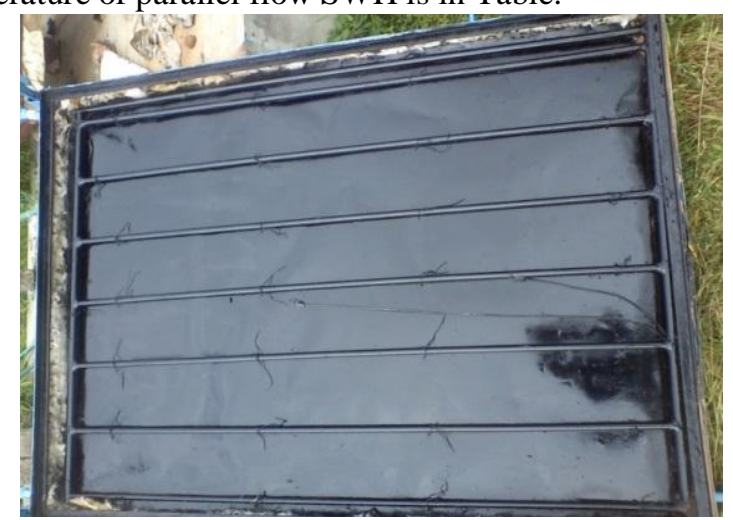

Fig. 10: Experimental setup - parallel flow SWH

Table. 2: DATA COLLECTION: PARALLEL FLOW SWH

\begin{tabular}{|l|l|l|l|l|}
\hline Time & $\begin{array}{l}\text { T in } \\
{\left[{ }^{\mathbf{}} \mathbf{C}\right]}\end{array}$ & $\begin{array}{l}\text { Tout } \\
{\left[{ }^{\mathbf{0}} \mathbf{C}\right]}\end{array}$ & $\begin{array}{l}\text { Level } \\
\text { Radiation } \\
\text { (solar) } \\
{[\mathbf{w} / \mathbf{m}]}\end{array}$ & $\begin{array}{l}\text { T out }- \text { T } \\
\text { in } \\
{\left[{ }^{\mathbf{C}} \mathbf{C}\right]}\end{array}$ \\
\hline 7.00 & 25 & 26 & 122 & 1 \\
\hline 7.30 & 27 & 28 & 126 & 1 \\
\hline 8.00 & 27 & 31 & 130 & 4 \\
\hline 8.30 & 30 & 36 & 138 & 6 \\
\hline 9.00 & 31 & 41 & 140 & 10 \\
\hline 9.30 & 33 & 46 & 153 & 13 \\
\hline 10.00 & 32 & 49 & 250 & 17 \\
\hline 10.30 & 31 & 51 & 301 & 20 \\
\hline 11.00 & 32 & 53 & 666 & 21 \\
\hline 11.30 & 33 & 55 & 540 & 22 \\
\hline 12.00 & 33 & 59 & 570 & 26 \\
\hline 12.30 & 34 & 60 & 664 & 26 \\
\hline 13.00 & 35 & 65 & 698 & 30 \\
\hline 13.30 & 34 & 69 & 928 & 35 \\
\hline 14.00 & 36 & 73 & 930 & 37 \\
\hline 14.30 & 35 & 70 & 840 & 35 \\
\hline 15.00 & 34 & 67 & 762 & 33 \\
\hline 15.30 & 33 & 61 & 698 & 28 \\
\hline 16.00 & 31 & 57 & 653 & 26 \\
\hline 16.30 & 29 & 51 & 520 & 22 \\
\hline 17.00 & 28 & 49 & 495 & 21 \\
\hline & & & & \\
\hline
\end{tabular}


The figure shows the complete setup of SFSWH. The outlet temperature of SFSWH is in Table.

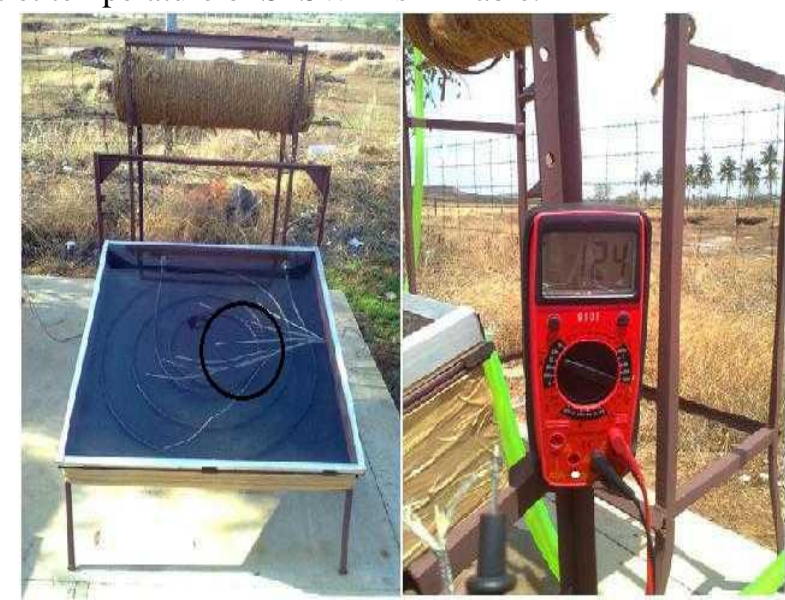

Fig. 11: Experimental setup - Spiral flow water heater

Table.3: DATA COLLECTION: SFSWH

\begin{tabular}{|c|c|c|c|c|c|c|}
\hline Time & $\begin{array}{l}\mathrm{T} \text { in } \\
{\left[{ }^{\mathbf{O}} \mathbf{C}\right.} \\
]\end{array}$ & $\begin{array}{l}\text { T out } \\
{\left[{ }^{\mathbf{0}} \mathbf{C}\right.} \\
]\end{array}$ & $\begin{array}{l}\mathbf{T} \\
\text { Glass } \\
{\left[{ }^{\mathbf{0}} \mathbf{C}\right]}\end{array}$ & $\begin{array}{l}\text { Level of } \\
\text { Radiati } \\
\text { on } \\
\text { (solar) } \\
\text { [w/m ] }\end{array}$ & $\begin{array}{l}\mathrm{T} \text { out } \\
\text { by } \\
\text { Thermo } \\
\text { meter } \\
{\left[{ }^{0} \mathrm{C}\right]}\end{array}$ & $\begin{array}{l}\mathbf{T} \text { out } \\
-\mathrm{T} \text { in } \\
{\left[{ }^{\mathbf{O}} \mathrm{C}\right]}\end{array}$ \\
\hline 7.00 & 23 & 24 & 24 & 176 & 23 & 1 \\
\hline 7.30 & 24 & 25 & 28 & 154 & 24 & 1 \\
\hline 8.00 & 24 & 33 & 31 & 255 & 29 & 9 \\
\hline 8.30 & 25 & 38 & 29 & 305 & 35 & 13 \\
\hline 9.00 & 27 & 42 & 32 & 540 & 39 & 15 \\
\hline 9.30 & 29 & 51 & 40 & 586 & 46 & 22 \\
\hline 10.00 & 30 & 58 & 55 & 642 & 52 & 28 \\
\hline 10.30 & 33 & 65 & 77 & 705 & 62 & 32 \\
\hline 11.00 & 34 & 70 & 83 & 812 & 69 & 36 \\
\hline 11.30 & 35 & 76 & 63 & 853 & 72 & 41 \\
\hline 12.00 & 37 & 80 & 77 & 890 & 76 & 43 \\
\hline 12.30 & 38 & 86 & 83 & 905 & 80 & 48 \\
\hline 13.00 & 41 & 87 & 78 & 860 & 82 & 46 \\
\hline 13.30 & 43 & 90 & 76 & 810 & 85 & 47 \\
\hline 14.00 & 44 & 93 & 77 & 709 & 86 & 49 \\
\hline 14.30 & 42 & 89 & 69 & 693 & 81 & 47 \\
\hline 15.00 & 38 & 82 & 71 & 535 & 76 & 44 \\
\hline 15.30 & 37 & 79 & 68 & 555 & 79 & 42 \\
\hline 16.00 & 37 & 63 & 62 & 429 & 63 & 26 \\
\hline 16.30 & 36 & 57 & 55 & 370 & 57 & 21 \\
\hline 17.00 & 34 & 53 & 48 & 199 & 53 & 19 \\
\hline
\end{tabular}

Natural circulation of parallel flow SWH and SFSWH is tested in kovilpatti at an interval of 30 minutes on that particular day (summer) between hour 7.00 to hour 17.00. Digital multimeter is used to measure the level of radiation (solar). Thermocouple $\mathrm{K}$ type is purposefully used to take the temperature readings at cold water inlet and hot water outlet as well as which is used to measure the temperatures at storage tank and ambient air.

\section{RESULTS}

The results obtained from TRNSYS and experimental test are plotted below.

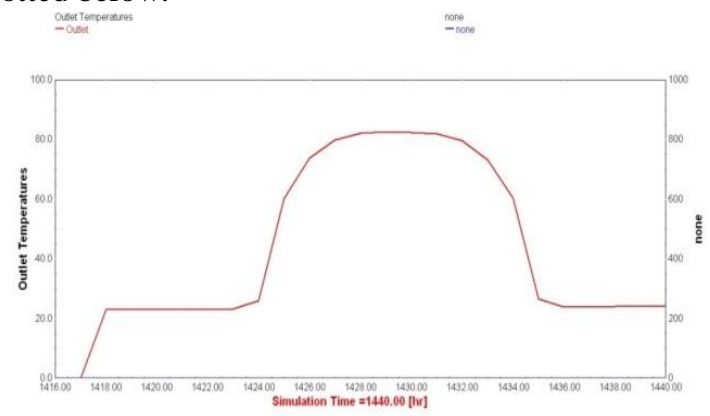

Fig 12(a) Parallel flow-Outlet Temperature

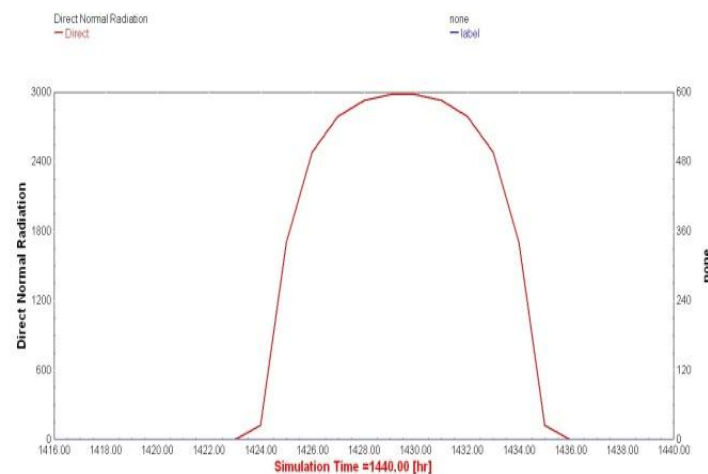

Fig. 12(b) Parallel flow-Direct Normal Radiation

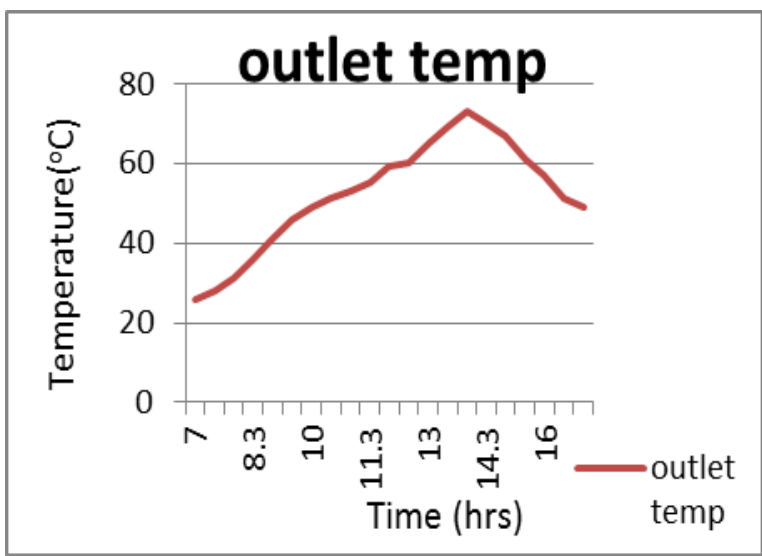

Fig. 12(c) Parallel flow-Outlet Temp. from actual reading

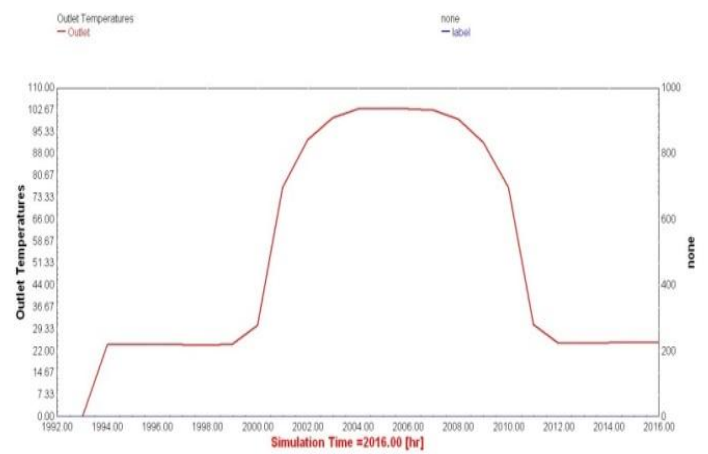

Fig. 13(a) Spiral flow-Outlet Temperature 


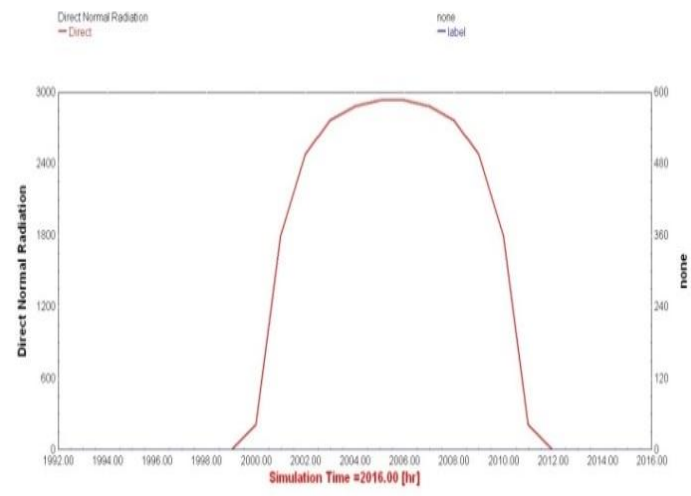

Fig. 13(b) Spiral flow-Direct Normal Radiation

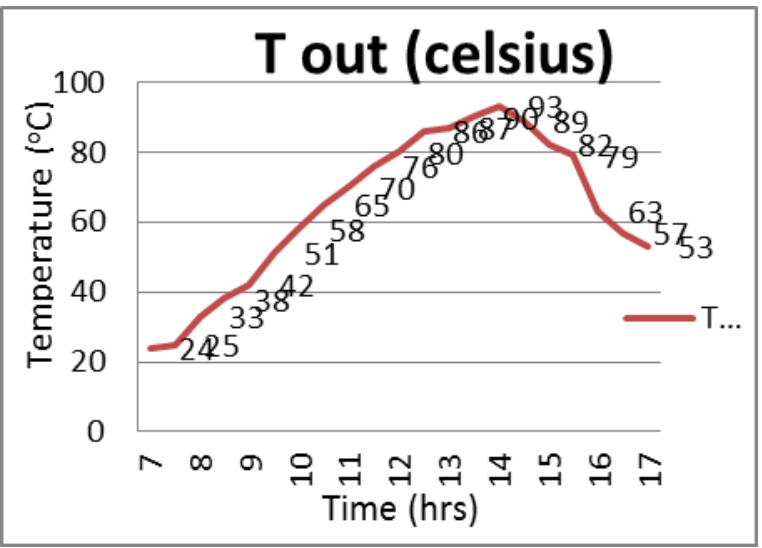

Fig. 13(c) Spiral flow- Outlet Temperature from actual reading
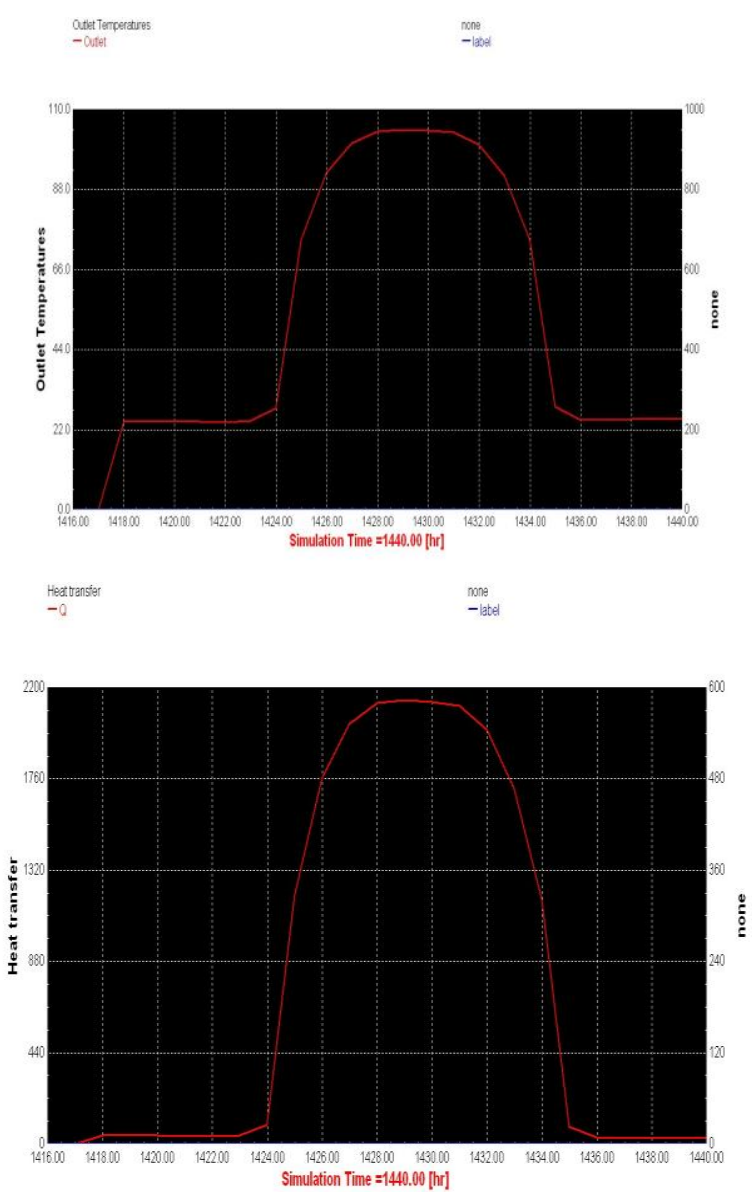

\section{APPENDIX}

The following data are input to TRNSYS weather data.

\section{Geometry Information}

\section{- Avalable Tables Solar Energy}

- Available Tables

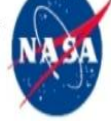

Latitude 9.17/ Longitude 77.87 was chosen.

Elevation: 307 meters Taken from the NASA GEOS-4 Model elevation

Northern boundary

10

Western boundary

Center

Eastern boundary

Latitude 9.5

78

Longitude 77.5

IJITEE 
Southern boundary

9

Monthly Averaged Insolation Incident on a Horizontal Surface $\left(\mathrm{kWh} / \mathrm{m}^{2} /\right.$ day $)$

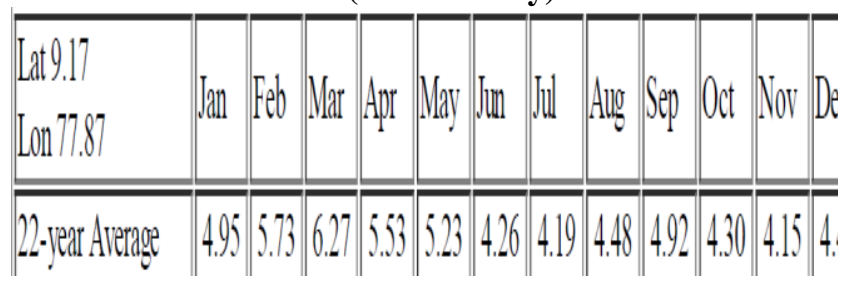

Monthly Averaged Midday Insolation Incident on a Horizontal Surface $\left(\mathrm{kW} / \mathrm{m}^{2}\right)$

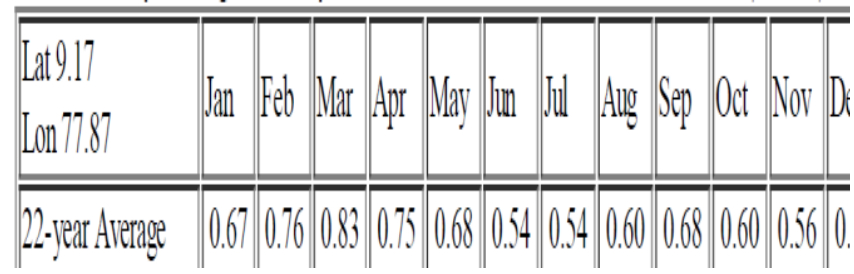

Monthly Averaged Diffuse Radiation Incident on a Horizontal Surface (kWh/m2/day)

\begin{tabular}{|c|c|c|c|c|c|c|c|c|c|}
\hline $\begin{array}{l}9.17 \\
177.87\end{array}$ & Feb & Mar Apr May Jun & & & & & & & Aver: \\
\hline & \begin{tabular}{|l|l|l|l|l|} 
\\
\end{tabular} & 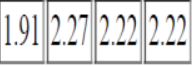 & ]$^{2}$ & & {$[t$} & & & & 2.05 \\
\hline inmom & \begin{tabular}{|l|l|}
1.43 & 1.44 \\
\end{tabular} & \begin{tabular}{l|l|l|l|l|l|l|l|l|l|}
1.64 & 2.11 & 2.18 \\
\end{tabular} & 2.162 & & 2.08 & & & & 1.9 \\
\hline vim & 1.872 .06 & \begin{tabular}{|l|l|l|l|l|l|l|l|l|} 
& 2.34 & 2.25 & 2.12 \\
\end{tabular} & & & & & & & 2.09 \\
\hline -jear & \begin{tabular}{|l|l|}
0.55 & 0.59 \\
\end{tabular} & \begin{tabular}{l|l|l|l|l|l|l|l|l|l|l|l|l|l|l|} 
& 0.52 & 0.50 & 0.41 \\
\end{tabular} & 0.40 & & & & & & \\
\hline Immom K & \begin{tabular}{|l|l|}
0.43 & 0.40 \\
\end{tabular} & \begin{tabular}{l|l|l|l|l|l|l|l|l|} 
& 0.37 & 0.33 \\
\end{tabular} & 0.33 & & & & & 39 & 0.39 \\
\hline & \begin{tabular}{|l|l|}
0.63 & 0.67 \\
\end{tabular} & \begin{tabular}{l|l|l|l|l}
77 & 0.58 & 0.55 & 0.49 \\
\end{tabular} & & & & & & .58 & 0.56 \\
\hline
\end{tabular}

Monthly Averaged Direct Normal Radiation (kWh/m2/day)

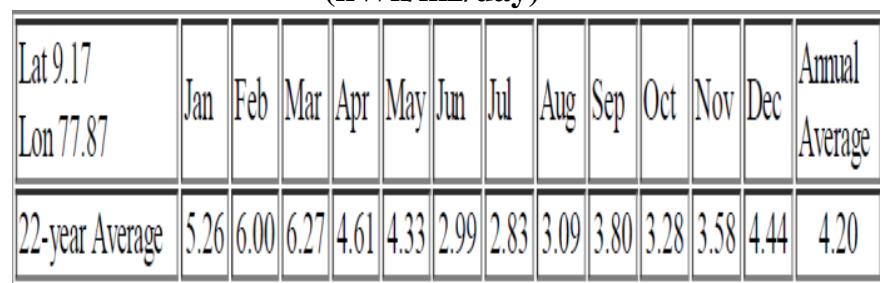

Monthly Averaged Air Temperature at $10 \mathrm{~m}$ above the Surface of the Earth $\left({ }^{\circ} \mathrm{C}\right)$

\begin{tabular}{|c|c|c|c|c|c|c|c|c|}
\hline $\begin{array}{l}\text { Lat9.17 } \\
\text { Lon } 77.87\end{array}$ & an $\mathrm{Feb}$ Mar & Apr May Jun . & (1) & Aug $\mathrm{Se}$ & & & & $\begin{array}{l}\text { Amulal } \\
\text { Average }\end{array}$ \\
\hline -jear Average & \begin{tabular}{l|l|l|}
24.1 & 25.8 & 27.0
\end{tabular} & \begin{tabular}{|l|l|l|}
26.0 & 25.5 & 24.8 \\
\end{tabular} & 24.6 & 24.824. & \begin{tabular}{c|c|}
9 & 24.5 \\
\end{tabular} & & 23.8 & 25.0 \\
\hline Minimum & \begin{tabular}{|l|l|l|}
20.5 & 21.6 & 2 \\
\end{tabular} & \begin{tabular}{|l|l|l|}
23.3 & 23.4 & 23.0 \\
\end{tabular} & 22.6 & 22.622. & 622.2 & & 20.7 & 222 \\
\hline Maximu & \begin{tabular}{ll|l}
28.2 & 30.1 & 31.4
\end{tabular} & \begin{tabular}{|l|l|l|}
29.3 & 28.2 & 27.0 \\
\end{tabular} & 27 & 2.50 & & & 27.3 & 28.2 \\
\hline
\end{tabular}

\section{REFERENCES}

1. Yanuar, N. Putra, Gunawan \& M. Baqi (2011) 'Flow and convective heat transfer characteristics of spiral pipe for nanofluids'- Journal of arpapress Vol7, Issue3, IJRRAS.

2. TRNSYS program manual. Madison, USA: Solar Energy Laboratory, University of Wisconsin; 2005.

3. Kalogirou SA. (2006) 'Prediction of flat-plate collector performance parameters using artificial neural networks', Journal of Solar Energy 2006; 80:248-59.

4. M.A.M. Rosli, S. Misha, K. Sopian, S. Mat, M.Yusof Sulaiman and E. Salleh (2014) 'Parametric Analysis on Heat Removal Factor for a Flat Plate Solar Collector of Serpentine Tube', World Applied Sciences Journal 29 (2): 184-187, 2014.

5. Agrawal B. and G.N. Tiwari (2010) 'Optimizing energy and energy of building integrated photovoltaic thermal (BIPVT) systems under cold climatic conditions', Journal of Applied Energy, 87(2): 417-426.

6. M.N.Mohammed, M.A.Alghoul, Kh.Abulqasem, Alshrif.mustafa, Kh.Glasia, P.Ooshaksaraei, M.Yahya, A.Zaharim and K.Sopian (2011) 'TRNSYS Simulation of Solar Water Heating System in Iraq', Journal of Recent Researches in Geography, Geology, Energy, Environment and Biomedicine.

7. M.A.M.Rosli, S.Misha, K.Sopian, S. Mat, M.YusofSulaiman and E. Salleh (2014) 'Parametric Analysis on Heat Removal Factor for a Flat Plate Solar Collector of Serpentine Tube', World Applied Sciences Journal 29 (2): 184-187, 2014.

8. I. Budihardjo, G.L. Morrison and M. Behnia (2003) 'Development of TRNSYS Models for Predicting the Performance of Water-in-Glass Evacuated Tube Solar Water Heaters in Australia', Journal of Destination Renewables - ANZSES 2003.

9. Gurjot S. Gill and Alan S. Fung (2011) 'Solar domestic hot water system analysis using TRNSYS', Journal of arpapress Vol 18

10. Thermo Dynamics Ltd. (2007), Solar Domestic Water Heating System, SB64-9PV, 2007.

11. Toronto Hydro (2007), Toronto Hydro Electric Systems, Electricity Rates and Time of Use, November 2007.

12. TRNSYS Reference Manual (2000) Klein, S.A., Beckman, W.A., Mitchell, J.W., Duffie, J.A., Duffie, N.A. and Freeman TL, Solar Energy Laboratory, University of Wisconsin, Madison.

13. TRaNsient SYstems Simulation program (TRNSYS), 2006, Version 16, Solar Energy Laboratory, University of Wisconsin, Madison, U.S., November 2006.

14. Perlman M, and Mills B.E., (1985) 'Development of Residential Hot Water Use Patterns', ASHRAE Transactions, Vol. 91, Part 2A, pp. 657-679. ASHRAE.

15. Adnan Ibrahim, Mohd Yusof Othman, Mohd Hafidz Ruslan, Sohif Mat, Kamaruzzaman Sopian (2011) 'Recent advances in flat plate photovoltaic/thermal (PV/T) solar collectors', Renewable and Sustainable Energy Reviews 15 (2011) 352-365.

16. Fabio Struckmann (2008) 'Analysis of a Flat-plate Solar Collector', a Project Report 2008 MVK160 Heat and Mass Transport, Lund, Sweden.

17. Tomas Matuska, Vladimir Zmrhal, and Juliane Metzger (2009) 'Detailed modeling of solar flat-plate collectors with design tool kolektor 2.2', Eleventh International IBPSA Conference, Glasgow, Scotland.

18. KhaledZelzouli, AmenallahGuizani, RamziSebai, ChakibKerkeni (2012) 'Solar Thermal Systems Performances versus Flat Plate Solar Collectors 
Connected in Series', a journal of Engineering, 2012, 4, 881-893.

19. R. Herrero Martin, A. Garcia Pinar, J. Perez Garcia (2011) 'Experimental heat transfer research in enhanced flat-plate solar collectors', World Renewable Energy Congress 2011- Sweden.

20. Y. Raja Sekhar, K. V. Sharma and M. Basaveswara Rao (2009) 'Evaluation of heat loss coefficients in solar flat plate collectors', ARPN Journal of Engineering and Applied Sciences.

21. Horia-Ionut PETCU, Adrian BADEA (2010) 'Theoretical and xperimental assessment of stationary and dynamic running of one flat plate solar collector', U.P.B. Sci. Bull., Series C, Vol. 72, Issue 2, 2010.

22. Maatouk Khoukhi, Shigenao Maruyama (2005) 'Theoretical approach of a flat plate solar collector with clear and low-iron glass covers taking into account the spectral absorption and emission within glass covers layer', a journal of Renewable Energy 30 (2005) 11771194.

23. Rui Li, Yanjun Dai, Ruzhu Wang (2015) 'Experimental investigation and simulation analysis of the thermal performance of a balcony wall integrated solar water heating unit', a journal of Renewable Energy 75 (2015) $115 \mathrm{e} 122$.

24. E. Massaguer, A. Massaguer, L. Montoro, J.R. Gonzalez (2014) 'Development and validation of a new TRNSYS type for the simulation of thermoelectric generators', a journal of Applied Energy 134 (2014) 65-74.

25. Veronique Delisle, Michael Kummert (2013) 'A novel approach to compare building-integrated photovoltaics/thermal air collectors to side-by-side PV modules and solar thermal collectors', a journal of Solar Energy 100 (2014) 50-65.

\section{AUTHORS PROFILE}

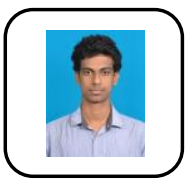

Selvadhurai M, Assistant professor/Mechanica department, Easwari Engineering College, Ramapuram, Chennai, Tamilnadu, India. Area of Research: Industrial Engineering Tools, Solar energy, Additive manufacturing.

Having an industry experience of two years and doing research on various concepts.

Email: selvadhuraimariappan@gmail.com

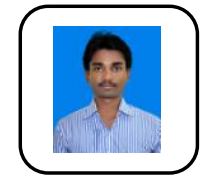

Vignesh ponmurugan S, Director, Ponmurugan \& co Constructions, Tuticorin, Tamilnadu, India. Area of Research: Renewable Energy sources, Solar thermal, Additive manufacturing.

Email: vigneshponmurugan.s@ gmail.com

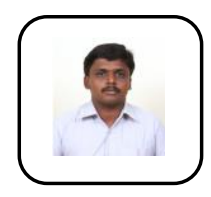

Vijayakumar R, Assistant professor/Mechanical department, National Engineering College, Kovilpatti, Tuticorin, Tamilnadu, India. Area of Expertise: Solar Thermal. Having more than three years of teaching experience.

Email: talk2vijayakumar89@gmail.com

Dillibabu V, Assistant professor/Mechanical department, Easwari Engineering College, Ramapuram, Chennai, Tamilnadu, India. Having more than five years of teaching experience. Published more than three papers in international journals.

Email: babudilli8@gmail.com 